\title{
Valuation of coastal ecosystem services in the Large Marine Ecosystems of Africa
}

3

\author{
Ewan Trégarot ${ }^{1}$, Grégoire Touron-Gardic ${ }^{1}$, Cindy C. Cornet ${ }^{1}$, Pierre Failler ${ }^{1}$
}

${ }^{1}$ Centre for Blue Governance, Department of Economics and Finance, Portsmouth Business School, University of Portsmouth, Richmond Building, Portland Street, Portsmouth PO1 3DE, United Kingdom.

*Corresponding author: ewan.tregarot@port.ac.uk

\begin{abstract}
The African coastline is bordered by highly valuable marine ecosystems, but the environmental degradation due to anthropogenic pressure alter the benefits that they render to people. Our paper aims at assessing the value of ecosystem services provided by mangroves, seagrass beds, coral reefs, and kelp forests present in the Large Marine Ecosystems (LMEs) of Africa. After the mapping of coastal marine habitats, our valuation relies on the transfer of value of all ecosystem services from reference monetary unit values, extracted from the literature. A habitat functionality index based on the assumption that a higher population density and a higher demographic growth rate lead to a decrease in the functionality and services of marine habitats was then defined and incorporated into the valuation. The surveyed coastal habitats cover about $117,000 \mathrm{~km}^{2}$, with seagrass beds being by far the most extensive habitat. Present all along the coasts of Africa, their surface area represents about $62 \%$ of surveyed coastal habitats, followed by the mangroves (23\%), coral reefs (15\%). Kelp forests are only present in the southern Benguela Current LME. We estimated the annual value of the LME's coastal ecosystem services at 814 billion USD. Coral reefs have the highest value ( 588 billion USD/year), followed by seagrass beds (135 billion USD/year), mangroves ( 91 billion USD/year), and kelp forests (0.4 billion USD/year). The results show that ecosystem services from the four coastal habitat types had the highest value in the Agulhas Current LME, representing $38 \%$ of the total value, followed by the Red Sea LME (28\%) and the Somali Coastal Current LME (10 \%). The three LMEs of the Atlantic side represent $15 \%$ of the total estimated value. Our paper highlighted many gaps that remain to be filled in terms of mapping and ecosystem services assessment in Africa. Nonetheless, our estimated values can facilitate dialogue between decision-makers and managers, and between countries sharing the same habitats and marine resources, toward better management of these ecosystems.
\end{abstract}

\section{Keywords}

Coastal marine habitats; Nature's contributions to people; Habitat functionality; Large Marine Ecosystems; Blue Economy 


\section{Introduction}

The African coastline, which is over 30,000 kilometers long, is subject to many pressures (UNEPWCMC, 2016a). Its natural habitats are damaged due to direct anthropogenic actions (resource extraction, environmental modification, pollution) and indirect actions such as climate change (UNEP-WCMC, 2016b; CBD, 2018). Thus, the surface area of natural coastal habitats such as mangroves, coral reefs, and seagrass beds has globally decreased in recent decades (with an annual loss of mangrove surface area of $2 \%$, for example) (IPBES, 2018). At the same time, the ecological condition of these habitats has deteriorated, leading to a loss of more than $50 \%$ of the live coral cover in coral reefs of the southwest Indian Ocean following the 1998 and 2016 bleaching events due to surface waters warming (UNEP-WCMC, 2016b; IPBES, 2018). Therefore, African coastal habitats' optimal functioning is hampered even though their functions are essential to maintain a suitable living environment for African and World populations.

In order to counteract this phenomenon, national and international institutions have mobilized to organize and harmonize public policies in favor of the coastal environment in Africa (Abidjan Convention, Nairobi Convention, Jeddha Convention, Convention on Biological Diversity, etc.). In this context, ecosystem-based approaches on a multi-national scale are becoming increasingly common. This is particularly true within Large Marine Ecosystem (LME) programs that often establish multinational diagnostics and strategic documents to optimize resources and natural spaces management within large-scale geographical areas, but also to guarantee a stable regional base in terms of human, institutional and scientific capacities and progress towards sustainable development (Satia, 2016). While public policies formerly focused on maintaining natural spaces and related biodiversity, they are now increasingly included in the process of reclaiming and enhancing degraded natural areas (Palmer and Filoso, 2009; Prober et al., 2019; Smith-Hall, 2009), in line with the United Nations' Sustainable Development Goals - SDG 15 (United Nations, 2015) and Aichi Targets 14 and 15 (CBD, 2010). In the current framework of the Intended Nationally Determined Contribution for the implementation of the Paris Agreement with particular consideration for blue carbon (UNECA, 2016; CMAE et al., 2019), or more conventionally in the achievement of Aichi Targets (Tittensor et al., 2014; Failler et al., 2019) and the implementation of Global Environment Facility (GEF)-funded programs related to LMEs (Sherman, 2019), the enhancement of coastal habitats has a leading role. In this regard, a monetary valuation is a relevant tool for integrating the environment into the economic, political, and social spheres (Binet et al., 2012; UNEP and GRID-Arendal, 2016). Quantifying ecosystem services in monetary terms allows us to compare different types of habitats and compare them with income-generating economic activities (Bacon et al., 2019; Bonnin et al., 2015). It also makes it possible to estimate the costs of political inaction (Trégarot et al., 2017), following the degradation of natural habitats. While the natural capital is often overlooked due to a lack of data compared to the human, social and economic capital (Failler et al., 2015; Pascal et al., 2018), this approach offers the advantage of emphasizing ecosystems in the planning of public policies. Choices in terms of investment for protection or conservation would be better informed if, for example, undervalued and previously overlooked habitats, such as seagrass beds, are taken into account. Monetary valuation of ecosystems further allows for greater balance in decision-making regarding the use of spaces: economic activities to the detriment of ecosystems versus risk-averse management of these ecosystems due to their high economic value. 
This article's objective is to present an economic valuation of the services provided by African coastal ecosystems. The economic value of these ecosystems is calculated from the surface area of the main African coastal habitats, namely mangroves, coral reefs, seagrass beds, and kelp forests, and considers their functionality in relation to anthropogenic stressors. We used Large Marine Ecosystems (LMEs) as a spatial unit for conservation purposes. Developed by Sherman and Alexander (1986), "LMEs are relatively large areas of ocean space $\left(>200,000 \mathrm{~km}^{2}\right)$ located along the margins of the continents. They are defined based on four ecological criteria: bathymetry (bottom depth); hydrography (water column structure); productivity; and trophic linkages" (Sherman, 2019). The LME concept enables ecosystem-based management to provide a collaborative approach to managing resources within ecologically bounded transnational areas. The method used is innovative since it incorporates the level of anthropogenic pressure to adjust the monetary valuation calculated using benefit transfer, where monetary assessments are usually limited to surface area data. The adjustment of the production function, which characterizes relationships between habitat condition and the delivery of economically valuable ecosystem services, by the ecological condition or the vulnerability of habitats was tested in the evaluation of ecosystem services for coral reefs and associated habitats (mangroves and seagrass beds), within the French Initiative for the Protection of Coral Reefs in French Overseas - IFRECOR (Failler et al., 2015; Trégarot et al., 2017). It was more recently applied to assess ecosystem services in the Banc d'Arguin National Park (PNBA), the largest marine protected area in West Africa (Trégarot et al., 2018). In the context of chronic lack of data and studies relating to African coastal and marine ecosystem services (Wangai et al., 2016; Willcock et al., 2016), this article presents, to our knowledge, the first exhaustive monetary study at the scale of the whole African continent for four essential coastal habitats. The geographic scale is unprecedented, considering that none of the monetary assessments that have already been conducted in Africa does exceed the regional level (Interwies, 2011; Interwies and Görlitz, 2013 in UNEP and GRID-Arendal, 2016), or individual LME level (Chukwuone et al., 2009). Moreover, they focused on few topics such as fishery resources (Sumaila, 2016), West African marine protected areas (Binet et al., 2012) and carbon sequestration (Bryan et al., 2020). Our approach can be re-used for similar work at other spatial scales (regional, national and local), particularly within the framework of the implementation of the African strategy relating to the blue economy, within which the enhancement of coastal ecosystems is a central concern.

The article is structured in three parts to present 1) the methods used for mapping and assessing ecosystem services considering the anthropogenic pressures; 2 ) a section giving the estimated value of coastal habitats per LME; 3 ) a discussion that integrates the main results into a broader reflection on the development challenges of the continent with its coastal environment.

\section{Method}

\subsection{Estimated surface area of coastal marine habitats}

The files digitizing the surface areas of coastal marine habitats targeted in this study (coral reefs, mangroves, and seagrass beds) are available on the Ocean Data Viewer database (available online at data.unep-wcmc.org). At the same time, we retrieved the distribution of kelp forests from Blamey and Bolton (2018). We determined coral reefs' surface area (UNEP-WCMC et al., 2018) considering only the surface areas that correspond to the African waters with the function "cutting" of the QGIS software (QGIS Development Team, 2020). Mangroves' surface area, then, was determined following 
the same process as coral reefs from the digitizing work of the Global Mangrove Watch project (Bunting et al., 2018), also available on Ocean Data Viewer. In this case, it was also necessary to use the automatic calculation function of QGIS to determine the surface area of the polygons digitized by Global Mangrove Watch. On the other hand, there is a lack of data on seagrass beds (Nordlund et al., 2018). The datasets present on Ocean Data Viewer are more likely to illustrate favorable distribution zones rather than existing contours (Bryan et al., 2020) even in the own view of some of their authors (Jayathilake and Costello, 2018). However, in the absence of suitable alternatives, our estimation of seagrass beds' surface area was based on UNEP's dataset (UNEP-WCMC and Short, 2017) made available through this platform.

In a second step, these habitats' surface areas were measured for each Large Marine Ecosystem bordering the African continent. The files digitizing the surface areas of mangroves, coral reefs, and seagrass beds were crossed with the digitized contours of these LMEs using the "cutting" function of QGIS.

The widely recognized NOAA classification of LMEs (IOC-UNESCO and UNEP, 2016) served as a reference. Thus, eight LMEs are bordering Africa: Agulhas Current LME (ACLME), Arabian Sea LME (ASLME), Benguela Current LME (BCLME), Canary Current LME (CCLME), Guinea Current LME (GCLME), Mediterranean Sea LME (MEDLME), Red Sea LME (RSLME) and Somali Coastal Current (SCCLME). One additional region was included because it occurs near the African continent and shares similar coastal marine habitats: the African islands of the Indian Ocean. The region of Cabo Verde was not included due to the 'absence' of habitats from the dataset of UNEP, despite the confirmed observation of coral reefs (Monteiro et al., 2008), seagrass beds (Creed et al., 2016), and kelp forests (Bolton, 2010). The spatial scale of Cape Verde Islands is also much smaller than the other LMEs and therefore requires a more refined evaluation. Furthermore, for the African Islands of the Indian Ocean, the Arabian Sea LME, the Mediterranean Sea LME and the Red Sea LME, we considered only the extent of each entity that was within the exclusive economic zones of the related African countries for our analyses. These LMEs and the additional region are illustrated in Figure 1, while the surface areas of coastal marine habitats within each LME and additional regions are presented in section 3.1 .

\subsection{Anthropogenic pressures and loss of functionality}

The ecological condition of habitats is often overlooked in the valuation of ecosystem services. However, the degradation of habitats condition alters the provisioning of their services and should, therefore, be accounted for (Culhane et al., 2020; Failler et al., 2010; Trégarot et al., 2017). In the absence of reliable data to assess marine habitats' ecological conditions in Africa, our paper examined the potential anthropogenic pressures as a proxy. Marine habitats exposed to stress are less resilient, i.e., more sensitive to disturbances, have reduced adaptive capacities, and have therefore an increased vulnerability (Folke et al., 2004; Moe et al., 2013). We assumed, then, that an increase in anthropogenic pressures is likely to decrease the ecological condition (i.e., increase the vulnerability) and the functionality of the habitat, and the supply of its services (Folke et al., 2004; Schröter et al., 2005). Indeed, human development is one of the main drivers of habitat degradation and loss of biodiversity (Cardinale et al., 2012) and a relatively good indicator of anthropogenic pressures. For instance, human population density has been previously related to water pollution levels (Nixon et al., 2003), forage fish declines (Greene et al., 2015), and sharks' distribution (WardPaige et al., 2010), while population growth rate has been previously related to species geographic 
range size (Di Marco and Santini, 2015) and ecosystems shifts (Tam et al., 2017). Therefore, we decided to consider both the population density and growth rate at the national scale in the absence of reliable information at the coastal level. The two parameters provide different information about the potential anthropogenic pressures and their effects on marine ecosystems.

On the one hand, population density indicates of the strength or magnitude of the anthropogenic pressures the ecosystems are likely to face. The higher the population density, the stronger the potential anthropogenic pressures (Creel, 2003; Nixon et al., 2003). The population growth rate, then, is more indicative of the temporality or trend of anthropogenic pressures. Indeed, while a relatively low growth rate reflects relatively stable stressors (or 'chronic pressures') to which ecosystems are more likely to be able to adapt, a relatively high rate reflects an increasing anthropogenic pressure to which ecosystems would be less likely to adapt, considering there would not be enough time for adaptive processes to occur (Dawson et al., 2010; Whitney et al., 2017). Consequently, we derived from these two parameters an index of habitat functionality as follows:

- We assumed that marine habitats in LMEs that were among the top $25 \%$ of LMEs globally for both parameters were facing acute and increasing anthropogenic pressures and, thus, only functioning at $25 \%$ of their optimal functional capacity, i.e., an index of functionality of 0.25 .

- In comparison, marine habitats in LMEs in the top $25 \%$ for one of the parameters but in the lower $75 \%$ for the other were considered as functioning at $50 \%$ of their optimal functional capacity (i.e., an index of functionality of 0.50 ), reflecting intermediate anthropogenic pressures (either strong but stable or low to moderate but increasing rapidly).

- Finally, we considered that marine habitats in LMEs in the lower $75 \%$ for both parameters were functioning at $75 \%$ of their optimal functional capacity (i.e., an index of functionality of $0.75)$, reflecting relatively low and stable anthropogenic pressures. In this last instance, we didn't consider an optimal functional capacity (i.e., 100\%) because both parameters, especially the population growth rate, were still above the average world values (United Nations, 2019).

\subsection{Economic Valuation}

We used Google Scholar to search for papers on the valuation of ecosystem services for the targeted habitats and selected recent reviews of economic values when they were available in the literature. We then classified the services following the Common International Classification of Ecosystem Services (CICES v5.1; Haines-Young and Potschin, 2018), avoiding as much as possible the risk of double counting, which may occur when assessing multiple ecosystem services using different nomenclatures or classifications, such as the Millennium Ecosystem Assessment (MA, 2005) and The Economics of Ecosystems and Biodiversity (TEEB, 2010). From the full list of ecosystem services, we selected the ones relevant to the marine environment (MARINE CICES Relevance $=1$ ) and selected the services applicable to the targeted habitats (expert knowledge). The literature review provided us with reference values (average value of several studies for a particular service) compiled in Table 1 , and which were standardized to 2018 USD using the world average inflation rate (consumer prices, annual \%) retrieved from The World Bank (2020).

The available reference values were then adjusted by multiplying them with the habitat functionality index $(0.25,0.50$, or 0.75$)$, and then multiplied by the surface area of coastal marine habitat for each LME. We considered the valuation of ecosystem services of kelp forests in South Africa (Blamey and 
212 Bolton, 2018) to reflect of the current habitat's functionality and did not require further adjustment.

213 However, to calculate the value of kelp forests in an optimal state, we divided the reference value

214 with the habitat functionality index. Our valuation method can be characterized by a benefit transfer

215 approach (without adjusting the value with the Gross Domestic Product of the countries because of

216 the spatial scale) fitted with a production function approach to account for the potential loss of

217 functionality (and ecosystem services) of habitats as a result of anthropogenic pressures. 

economic value of marine ecosystem services per African Large Marine Ecosystem.

\begin{tabular}{|c|c|c|c|c|c|c|}
\hline & Code & CICES Class & $\begin{array}{c}\text { Mangroves } \\
\text { [USD/ha/year] }\end{array}$ & $\begin{array}{c}\text { Coral reefs } \\
\text { [USD/ha/year] }\end{array}$ & $\begin{array}{l}\text { Seagrass beds } \\
\text { [USD/ha/year] }\end{array}$ & $\begin{array}{c}\text { Kelp forests } \\
\text { [USD/km/year] }\end{array}$ \\
\hline \multirow{7}{*}{ 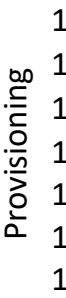 } & 1.1.5.1 & Wild plant used for nutrition & na & na & na & nd \\
\hline & 1.1.5.2 & Fibres and other materials from wild plants for direct use or processing & \multirow{2}{*}{$3,417^{\mathrm{d}}$} & na & $11,580^{\mathrm{e}}$ & $2,428^{\mathrm{a}}$ \\
\hline & 1.1.5.3 & Wild plant used as a source of energy & & na & nd & $\mathrm{nd}$ \\
\hline & 1.1.6.1 & Wild animals used for nutritional purposes & $10,574^{d}$ & $965^{b}$ & $1,481^{\mathrm{e}}$ & $179,230^{\mathrm{a}}$ \\
\hline & 1.1.6.2 & Fibres and other materials from wild animals for direct use or processing & nd & $31,359^{\mathrm{b}}$ & nd & nd \\
\hline & 1.2.1.1 & Seeds, spores and other plant materials collected for maintaining or establishing population & nd & na & nd & nd \\
\hline & 1.2.2.1 & Animal material collected for maintaining or establishing population & nd & $47,107^{b}$ & nd & nd \\
\hline & 2.1.1.1 & Bio-remediation by micro-organisms, algae, plants, and animals & \multirow{2}{*}{$3,593^{\mathrm{d}}$} & \multirow{2}{*}{$121^{\mathrm{b}}$} & $23,237^{e}$ & Part of 2.2.6.1 \\
\hline & 2.1.1.2 & Filtration/Sequestration/storage/accumulation by micro-organisms, algae, plants, and animals & & & nd & na \\
\hline § & 2.2.1.1 & Control of erosion rates & $1,182^{\mathrm{d}}$ & $218,391^{\mathrm{b}}$ & $4,803^{\mathrm{c}}$ & $\mathrm{nd}$ \\
\hline 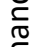 & 2.2.1.3 & Hydrological cycle and water flow regulation (including flood control, and coastal protection) & $2,143^{\mathrm{d}}$ & $24,219^{b}$ & nd & nd \\
\hline & 2.2.2.1 & Pollination (Gamete dispersal) & nd & $23,106^{\mathrm{b}}$ & nd & $\mathrm{nd}$ \\
\hline & 2.2.2.2 & Seed dispersal & nd & nd & nd & nd \\
\hline & 2.2.2.3 & Maintaining nursery populations and habitats (including gene pool protection) & $1,975^{d}$ & nd & $136^{\mathrm{e}}$ & nd \\
\hline & 2.2.3.1 & Pest control & \multirow{2}{*}{$1,013^{\mathrm{d}}$} & nd & nd & nd \\
\hline & 2.2.3.2 & Disease control & & nd & nd & nd \\
\hline & 2.2.4.2 & Decomposition and fixing processes and their effect on soil quality & $544^{\mathrm{d}}$ & na & nd & na \\
\hline & 2.2.5.2 & Regulation of the chemical condition of salt waters by living processes & $1,016^{\mathrm{d}}$ & nd & nd & nd \\
\hline & 2.2.6.1 & Regulation of chemical composition of atmosphere and oceans & \multirow[b]{2}{*}{$44,178^{\mathrm{d}}$} & $1,693^{b}$ & $413^{c}$ & $147,540^{\mathrm{a}}$ \\
\hline & 2.2.6.2 & Regulation of temperature and humidity including ventilation and transpiration & & na & na & na \\
\hline & 3.1 .1 & $\begin{array}{l}\text { Characteristics of living systems that enable activities promoting health, recuperation or } \\
\text { enjoyment through active or immersive interactions }\end{array}$ & $4,482^{d}$ & $137,269^{\mathrm{b}}$ & nd & $115,839^{\text {a }}$ \\
\hline & 3.1.2.1 & ... that enable scientific investigation or the creation of traditional knowledge & \multirow[t]{2}{*}{$351^{d}$} & \multirow[t]{2}{*}{$1,632^{\mathrm{b}}$} & nd & \multirow{2}{*}{$72^{\mathrm{a}}$} \\
\hline & 3.1.2.2 & ...that enable education and training & & & nd & \\
\hline$\overline{\widetilde{0}}=$ & 3.1.2.3 & ...that are resonant in terms of culture or heritage & \multirow{2}{*}{$325^{d}$} & nd & nd & nd \\
\hline & 3.1.2.4 & ... that enable aesthetic experiences & & $16,235^{b}$ & nd & nd \\
\hline & 3.2.1.1 & Elements of living systems that have symbolic meaning & nd & nd & nd & nd \\
\hline & 3.2.1.2 & Elements of living systems that have sacred or religious meaning & nd & nd & nd & nd \\
\hline & 3.2.1.3 & ...used for entertainment or representation & nd & nd & nd & $\mathrm{nd}$ \\
\hline & 3.2.2.1 & ...that have an existence value & nd & nd & nd & nd \\
\hline & 3.2.2.2 & ... that have an option or bequest value & nd & nd & nd & nd \\
\hline
\end{tabular}




\section{Results}

\subsection{Surface areas of coastal marine habitats}

Based on our mapping, the combined extent of coral reefs, mangroves, and seagrass beds was estimated at approximately $117,000 \mathrm{~km}^{2}$, following a heterogeneous distribution. Seagrass beds, which are present all along the coasts of Africa, are the most extensive ecosystem with an estimated surface area of more than $72,000 \mathrm{~km}^{2}$ (Table 2). The mangroves come next, with a surface area of $27,465 \mathrm{~km}^{2}$, distributed between Mauritania in the north and Angola in the south for the Atlantic coast, while they are present on the entire eastern coast from the north of South Africa (Figure 1). Coral reefs, then, represent a total surface area of $17,121 \mathrm{~km}^{2}$. No surface area was given for kelp forests, which dominate the nearshore environment in the southern region of the Benguela Current LME, covering approximately $1,000 \mathrm{~km}$ of the coastline (Blamey and Bolton, 2018).

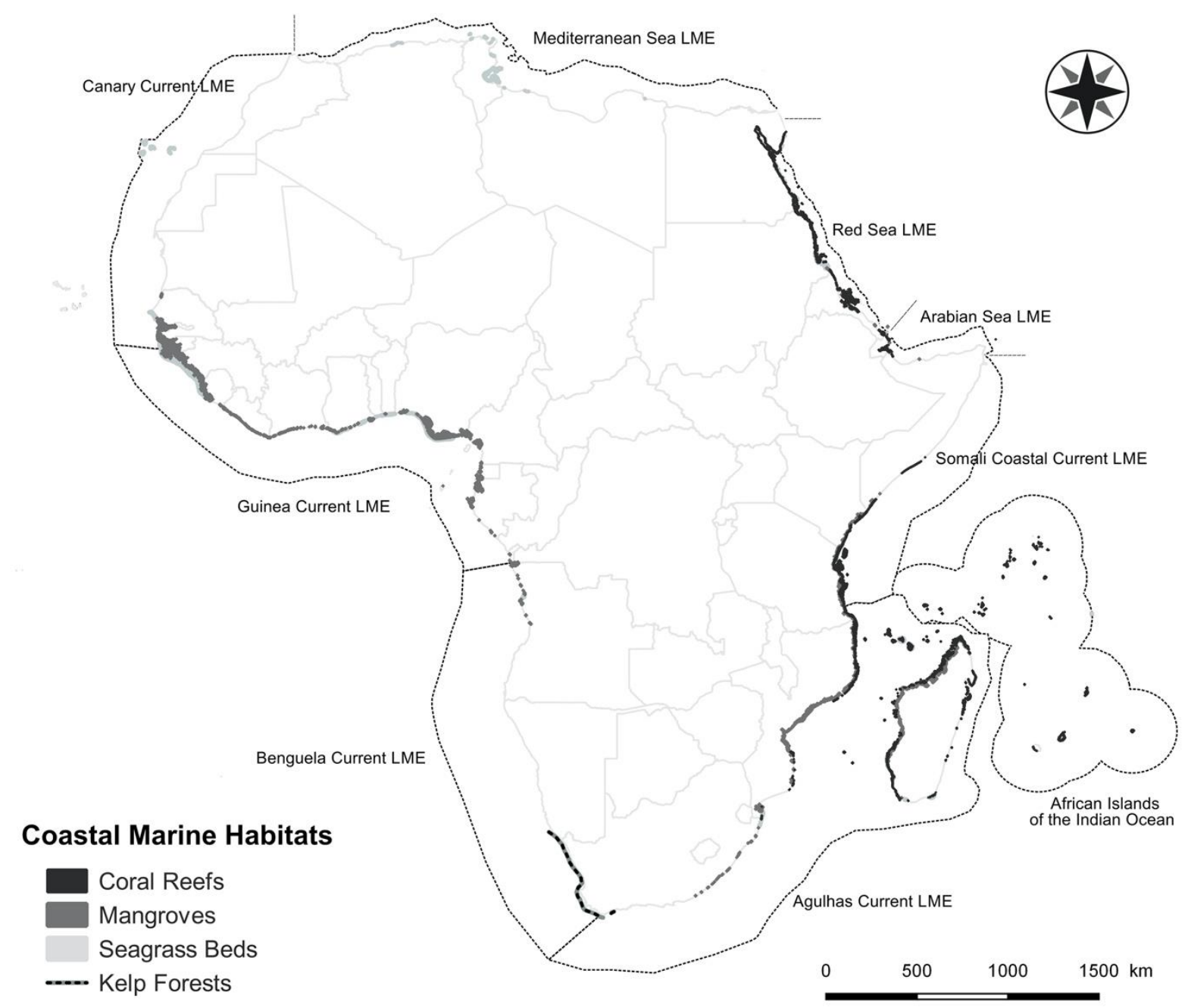

Figure 1. Distribution of the main coastal marine habitats along African waters, and their divisions into the Large Marine Ecosystems and the additional region.

Seagrass beds are particularly abundant along the Guinea Current LME (Table 2). More importantly, they are present in 8 out of 9 LMEs and additional regions of Africa. Mangroves are mainly located along West Africa in the Guinea Current LME (over $16,000 \mathrm{~km}^{2}$, representing almost $60 \%$ of the total area). However, a significant area is also present in the Agulhas Current $\operatorname{LME}\left(5,792 \mathrm{~km}^{2}\right.$, equivalent 
to $21 \%$ of the total area). The Agulhas Current LME is also the LME within which the coral surface area is the largest (more than 6,400 $\mathrm{km}^{2}$ ), followed by the Red Sea LME (more than 5,400 $\mathrm{km}^{2}$ ).

Table 2. Surface areas (or linear coastal length - kelp forests) of the main coastal marine habitats along African waters, and their divisions into the Large Marine Ecosystems and additional region.

\begin{tabular}{|c|c|c|c|c|c|}
\hline $\begin{array}{l}\text { Large Marine Ecosystems (LME) } \\
\text { and the additional region }\end{array}$ & $\begin{array}{r}\text { Coral reefs } \\
{\left[\mathrm{km}^{2}\right]}\end{array}$ & $\begin{array}{r}\text { Mangroves } \\
{\left[\mathrm{km}^{2}\right]}\end{array}$ & $\begin{array}{r}\text { Seagrass beds } \\
{\left[\mathrm{km}^{2}\right]} \\
\end{array}$ & $\begin{array}{r}\text { Combined } \\
{\left[\mathrm{km}^{2}\right]} \\
\end{array}$ & $\begin{array}{r}\text { Kelp forests } \\
{[\mathrm{km}]}\end{array}$ \\
\hline African Islands of the Indian Ocean & 2,285 & 8 & 134 & 2,427 & 0 \\
\hline Agulhas Current LME & 6,442 & 5,792 & 9,714 & 21,948 & 0 \\
\hline Arabian Sea LME & 408 & 11 & 0 & 419 & 0 \\
\hline Benguela Current LME & 0 & 617 & 601 & 1,217 & 1,000 \\
\hline Canary Current LME & 0 & 3,212 & 6,195 & 9,407 & 0 \\
\hline Guinea Current LME & 0 & 16,195 & 43,582 & 59,777 & 0 \\
\hline Mediterranean Sea LME & 0 & 0 & 5,065 & 5,065 & 0 \\
\hline Red Sea LME & 5,481 & 76 & 6,963 & 12,521 & 0 \\
\hline Somali Coastal Current LME & 2,844 & 1,555 & 160 & 4,559 & 0 \\
\hline Total & 17,460 & 27,465 & 72,415 & 117,339 & 1,000 \\
\hline
\end{tabular}

The LME with the greatest combined surface areas of coral reefs, mangroves, and seagrass beds is by far the Guinea Current LME with 60,000 km², followed by the Agulhas Current LME with 22,000 $\mathrm{km}^{2}$ (Table 2). Among the other large LMEs, the Arabian Sea LME and the Benguela Current LME are less luxuriant.

\subsection{Anthropogenic pressures over Large Marine Ecosystems in Africa}

With the third highest population density and the second highest population growth rate, the marine habitats of the Guinea Current LME are facing the most substantial anthropogenic pressures of African LMEs (see Table A1 in Annex). They are the only ones to be considered to function at only $25 \%$ of their capacity. Then, the marine habitats of the African Islands of the Indian Ocean, the Arabian Sea LME, and the Somali Coastal Current LME face more moderate anthropogenic pressures of different intensity and temporal changes and are thus considered functional at $50 \%$ of their optimal capacity. Indeed, on the one hand, the African Islands of the Indian Ocean are presenting the highest population density, about ten times higher than the average population density in the African LMEs. They also present the lowest population growth rates, meaning their marine habitats face strong but relatively stable anthropogenic pressures. On the other hand, the Arabian Sea and the Somali Coastal Current LMEs have two of the highest population growth rates (more than twice the average world value), but relatively low population densities, meaning their marine habitats face relatively low but quickly increasing anthropogenic pressures. Finally, the Agulhas Current, the Benguela Current, the Canary Current, the Mediterranean Sea, and the Red Sea LMEs present relatively low population densities and moderate population growth rates above the average world value. Accordingly, we considered their marine habitats to have higher functionality (75\%) since they were experiencing low to moderate and relatively stable anthropogenic pressures. 


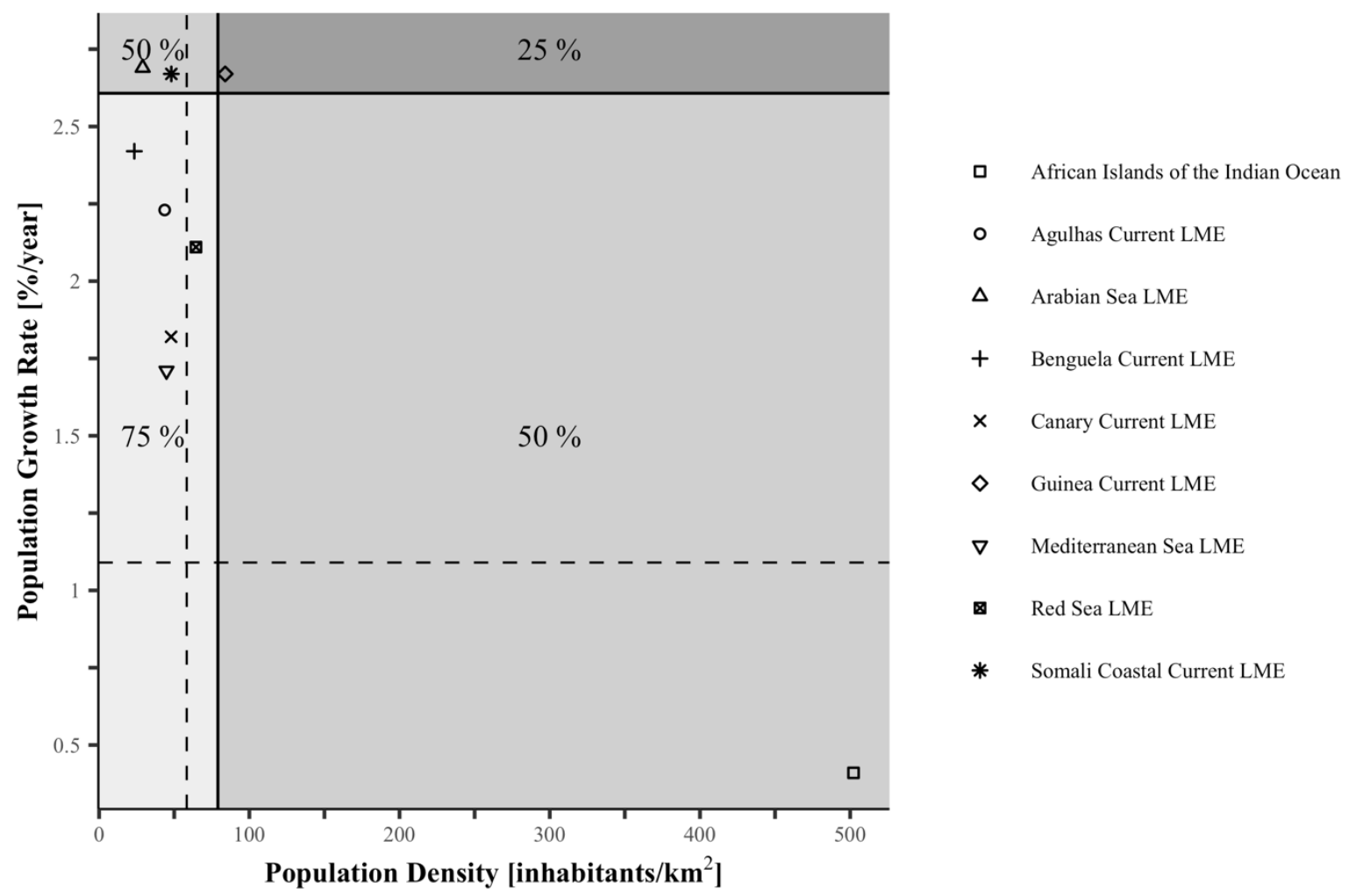

Figure 2. African LMEs habitat functionality index according to their population density and growth rate. Solid lines represent the $75 \%$ quantile while dotted lines represent the average World value over the 2015-2020 according to the United Nations (2019).

\subsection{Economic valuation of African Large Marine Ecosystems}

Table 1 shows that many services remain to be valued for all habitats, especially cultural services. It also shows the overlap of different services, when valuations are based on previous classifications, confirmed by Czúcz et al. (2018). Also, the risk of double-counting can arise when valuing different services and is particularly high for cultural services (LUC, 2015). Some of the supporting and regulating services, such as maintaining nursery populations and habitats (including gene pool protection), are inputs for provisioning services. However, we found few reference values for the cultural services, and given the numerous services that could not be valued, our approach remains most likely conservative. Based on the available reference values, the sum of ecosystem services values reaches 352,250 USD/ha/year for coral reefs, 58,842 USD/ha/year for mangroves, and 41,413 USD/ha/year for seagrass beds. For kelp forests, the average value per km of coastline in South Africa was estimated at 445,109 USD/km/year, considering the current habitat functionality and productivity. Note that those values do not represent the Total Economic Value, as developed by Ledoux and Turner (2002).

To estimate the economic value of coastal marine habitats in each LME and additional regions of Africa (Table 3), we applied the habitat functionality index (Figure 2) to the average values of marine habitats to adjust the production function. By doing this, we estimated the value of marine ecosystem services in Africa from the four coastal habitat types at 814 billion USD annually, with coral reefs having the highest value (588 billion USD/year), followed by seagrass beds (135 billion 
USD/year), mangroves (91 billion USD/year) and kelp forests (0.4 billion USD/year). The results show that of the African LMEs, the value of ecosystem services from coastal habitats was highest for the Agulhas Current LME, representing $38 \%$ of the total value in Africa, followed by the Red Sea LME (28 \%). The Somali Coastal Current LME, the Guinea Current LME, and African Islands of the Indian Ocean each represent between 10 and $7 \%$ of our estimated value in Africa $(9.5 \%, 9.3 \%$, and $7.1 \%$, respectively) while the other LMEs represent less than $5 \%$ each (Canary Current LME: $4.6 \%$; Mediterranean Sea LME: 1.9 \%; Arabian Sea LME: $1.3 \%$; Benguela Current LME: 0.7 \%).

Table 3. Economic value of marine ecosystem services per African Large Marine Ecosystem, expressed in million USD/year, adjusted by the habitat functionality index for each LME (estimated values), and comparison with reference values.

\begin{tabular}{|c|c|c|c|c|c|}
\hline $\begin{array}{l}\text { Large Marine Ecosystems (LME) } \\
\text { and the additional region of Africa }\end{array}$ & Mangroves & $\begin{array}{r}\text { Seagrass } \\
\text { beds }\end{array}$ & Coral reefs & $\begin{array}{r}\text { Kelp } \\
\text { forests }\end{array}$ & Total \\
\hline African Islands of the Indian Ocean & 31 & 279 & 57,352 & - & 57,662 \\
\hline Agulhas Current LME & 32,491 & 30,345 & 242,573 & - & 305,408 \\
\hline Arabian Sea LME & 41 & - & 10,245 & - & 10,286 \\
\hline Benguela Current LME & 3,459 & 1,876 & - & 445 & 5,780 \\
\hline Canary Current LME & 18,017 & 19,351 & - & - & 37,368 \\
\hline Guinea Current LME & 30,282 & 45,379 & - & - & 75,661 \\
\hline Mediterranean Sea LME & - & 15,822 & - & - & 15,822 \\
\hline Red Sea LME & 426 & 21,752 & 206,411 & - & 228,589 \\
\hline Somali Coastal Current LME & 5,813 & 334 & 71,388 & - & 77,535 \\
\hline Total (reference values) & 205,422 & 301,602 & 876,615 & 593 & $1,384,233$ \\
\hline Total (estimated values) & 90,561 & 135,137 & 587,967 & 445 & 814,111 \\
\hline$\%$ & $44 \%$ & $45 \%$ & $67 \%$ & $75 \%$ & $59 \%$ \\
\hline
\end{tabular}

310 Using the reference values only, the value of marine ecosystem services in Africa would reach 1,384 billion USD/year (Table 3). By considering the potential loss of services due to the demographic pressure (derived habitat's functionality index), results showed a monetary value that is only $59 \%$ of this 'maximal' value. It also indicates that mangroves might be the habitat suffering the most from the demographic pressure ( $44 \%$ of the 'maximal' value).

\section{Discussion}

Assessing the value of ecosystem services is essential to facilitate the dialogue with and between decision-makers and make choices about public investment. It helps to formulate sound policies for both economic development and nature conservation.

The first key outcome of the valuation is that coral reef is the most important habitat, with $72 \%$ of the value generated ( $17 \%$ from seagrass beds, $11 \%$ from mangroves, and $0.06 \%$ from kelp forests). Despite a surface area fourfold smaller than seagrass beds, coral reefs' unit value is much higher thanks to their highly valued control in erosion rates and their support to activities promoting health, recuperation or enjoyment through active or immersive interactions. Cold-water corals, that were omitted in this valuation, are also largely represented in West Africa (Hebbeln et al., 2019; Ramos et al., 2017; Yesson et al., 2012), and provide habitat and refuge for many fish of commercial value and invertebrates. 
Support of commercial fisheries probably represents the most important services offered by coldwater corals (Foley and Armstrong, 2010). Scientific knowledge for this habitat (i.e., distribution, depth range, biodiversity, functionality, ecosystem services), in Africa and other regions of the world, is still at its infancy due to the limited accessibility (Freiwald et al., 2004). Mangroves have a higher unit value than seagrass beds, by $40 \%$, but seagrass beds' extent is much larger, distributed from the Mediterranean Sea to Southern Africa. Despite the broad distribution of seagrass beds in Africa, this habitat remains poorly characterized, at the image of the uncertainty behind their distribution. Seagrass beds are probably one of the most unknown habitats in West Africa due to the difficulty of detecting them using remote sensing because of coastal waters' turbidity. Even emblematic region such as the National Park of Banc d'Arguin in Mauritania, created in 1976, and well known for its vast extents of seagrass beds, estimated at $674 \mathrm{~km}^{2}$ (Trégarot et al., 2018) is not represented and were still not considered in the revision of seagrass distribution by McKenzie et al. (2020). Seagrass has, however, faced an increasing interest in the past few years with the growth of Blue Carbon (Lavery et al., 2013) and their potential contribution as a carbon sink. The distribution of seagrass beds in West Africa is currently being revised through the project ResilienSea (resiliensea.org). Their presence in most LMEs and the additional region merits special attention from policymakers to strengthen the conservation and restoration efforts at larger scales.

The second key outcome is that the potential value of the ecosystem services, not considering their ecological condition, is about 1,384 billion USD compared to 814 billion USD when considering the effect of the population growth and the associated habitat perturbation and degradation (derived habitat functionality index). If demographic pressures without appropriate management measures reduced the functionality of the four coastal habitat types to the degrees supposed in this study, the estimated annual loss of about 570 billion USD corresponds to the absence of additional policy or policy revision to prevent environmental damages, also referred as the cost of policy inaction (Braat et al., 2008; Failler et al., 2010). The value of ecosystem services will likely continue to decline in the future without appropriate policies to address the increasing pressure due to population growth along the African coasts. The recent African Union Blue Economy Strategy seeks to address this issue by providing means of intervention for regions and countries (AU-IBAR, 2019). The Indian Ocean Commission is also addressing this issue with its Blue Economy Regional Action Plan, where a specific focus is made on the enhancement of coastal urban ecosystems for the improvement of the public health and people's wellbeing in general.

Compared to other valuation studies on African LMEs, Chukwuone et al. (2009) estimated the Direct Output Value at 49,914 million USD for the Guinea Current LME, considering marine fishery, offshore oil production, Non-Timber Forest Product (periwinkle), and mining. In our study, our evaluation reaches 75,661 million USD, which is in the same order of magnitude despite a different approach and different habitats and services. Environmental goods and services from African LMEs were also estimated at 139 billion USD per year (Hamukuaya, 2011) with 22 billion USD for Agulhas and Somali Current LMEs, 54.3 billion USD for the Benguela Current LME, 11.7 billion USD for the Canary Current LME, and 51 billion USD for the Guinea Current LME (Hamukuaya, 2011 in Satia 2016). In our study, the total value reaches 502 billion USD for those LMEs. The most significant difference is for the Agulhas and Somali Current LMEs, with a 383 billion USD value. However, we could not find the reference within Satia (2016), making the comparison difficult. The average value of the LMEs and the 
additional region in Africa was estimated at 90 billion USD per year, which, compared to the Bay of Bengal LME, is in the same order of magnitude, estimated at 72 billion USD (BOBLME, 2014).

\subsection{Intended use of ecosystem services valuation}

Over the last decades, ecosystem valuation has become a convincing way of demonstrating the economic gains and value-added associated with marine and coastal conservation. As useful as this kind of information on benefits is for advocacy and awareness purposes, it is, nevertheless, important to underline that economic valuation is not an end in itself. Instead, it should be seen as a means to an end - better and more informed decision-making (Emerton, 2013). Therefore, our main concern is incorporating valuation results into the implementation of African LMEs projects and their respective Strategic Action Programmes. Indeed, although there have been great achievements and advances made by African LME Programmes to constitute a solid foundation on which to build and move forward (Satia, 2016), about 90\% of all the Transboundary Diagnostic Analysis-Strategic Action Programme (TDA-SAP) processes undertaken so far include the need for a cost-benefit analysis or value chain analysis to justify political support for the ecosystem-based management approach and to strengthen protection for ecosystem resilience (UNDP, 2017). Fisheries is one good example for which the desire to maximize added value often results in the overexploitation of the resources shared between several countries (Munro, 1979; Clark, 1990). The three BCLME countries have already established the Benguela Current Commission (BCC) as a fully-fledged regional cooperative management body for the Benguela Current Large Marine Ecosystem (Sumaila, 2016). Similar management initiatives in Africa's other LMEs would be an important addition to the marine environment's current management framework. Given the urgency to upscale restoration efforts, LMEs provide a suitable framework and management tool to reversing the degradation and general loss of biodiversity and introduce an ecosystem approach to managing the living marine resources to sustain the good and services of LMEs for the well-being of livelihoods in Africa.

At a more regional or local scale, this evaluation could be a starting point for some regions that do not have ecosystem services valuations to rely on. The simple transfer of value of ecosystem services from reference monetary unit values is an approximation at best and must be interpreted with the utmost care. But this method has the advantage of being easily implemented in data-scarce regions. The unit reference values of habitats can be used locally, with little adjustments, considering the Gross Domestic Product and the socio-economic and environmental contexts. Valuation estimates can support arguments for establishing Marine Protected Areas when the benefits of such designations outweigh the costs and, more generally, can inform the "preservation versus development" debate in coastal areas. In return, the creation of Marine Protected Areas contributes to achieving the Aichi target 11 and SDG 14 - target 14.5, which is to effectively conserve $10 \%$ of coastal and marine areas by 2020 (CBD 2010; United Nations 2015). Our results may also support market solutions such as Payment for Ecosystem Services schemes (Palmer and Filoso, 2009). PES schemes, such as 'Reducing Emissions from Deforestation and Degradation' (REDD+), incentivize conservation through 'avoided deforestation', with a service buyer paying a service provider to store carbon that would otherwise be emitted due to land cover change. Payments for avoided deforestation are rapidly gaining traction in the marine environment, mainly through mangrove research and policymaking under the term 'blue carbon' (Mcleod et al., 2011; Sutton-Grier and Moore, 2016). In fact, many countries are including Blue Carbon in their revised Nationally 
Determined Contributions (Herr and Landis, 2016) with carbon market makers such as Verra (formerly Verified Carbon Standard; VCS; https://verra.org) creating methodologies and standards for seagrass carbon sequestration as well as regional bodies such as IORA (Indian Ocean Rim Association) initiating regional Blue Carbon Think Tanks, among other efforts (https://www.iora.int).

\subsection{Limitations and Future research}

420

421

422

423

424

425

426

427

428

429

430

431

432

433

434

435

436

437

438

439

440

441

442

443

444

445

446

447

448

449

450

451

452

453

454

455

456

The valuation of ecosystem services using benefit transfer presents many drawbacks, namely the tendency to overestimate, the inaccuracy that arises when the original value was calculated in very different biophysical, ecological and socio-economic characteristics, or the risk of recycling old values (see Himes-Cornell et al. (2018b) and references within). Furthermore, there are substantial risks and uncertainties associated with our assessment. First, the use of a single monetary value in this study may suggest a false precision, whilst decision-makers should interpret the values having the uncertainties and limitations in mind. The current state of knowledge requires that we simplify complex ecological systems into single economic goods that we are able to value (Cole and Moksnes, 2016). Our valuation aims not to provide precise estimates of ecosystem services at this scale but to highlight the benefits and goods coastal marine habitats offer to people in Africa. As Costanza et al. (2017) mentioned: "there is not one right way to assess and value ecosystem services. There is however a wrong way, that is, not to do it at all". Furthermore, the monetary value should be considered within the local environmental context (ecological and social). For instance, the service of coastal protection and its value could also be calculated with the damage avoided cost (Pascal et al., 2016). Although some habitats do not protect human infrastructure and hence should have a lower monetary value, their natural importance to protect terrestrial habitats, for instance, breeding colonies of seabirds at risk of flooding on low elevated islands in Mauritania (Veen et al., 2018), should nonetheless be recognized. On the other hand, the service of coastal protection is vital in regions at risks of extreme climatic events (i.e., cyclone), such as South-East Africa (Cabral et al., 2017; Devi, 2019) or in West Africa, where coastal erosion rates have been substantial over the past decades (Ndour et al., 2018).

Secondly, the mapping of coastal marine habitats is an obvious source of uncertainty, especially seagrass beds, for which the surface area is still a gross approximation. Also, kelp forests are probably not limited to the Benguela Current LME, according to the distribution of laminarian globally (Wernberg et al., 2019), but might also be present in the Canary Current LME and the southern Agulhas Current LME. The distribution of coral reefs and mangroves are considered reasonably representative of the reality at this spatial resolution. Indeed, the surface areas of coral reefs from UNEP-WCMC et al. (2018) is consistent with the ones from The Nature Conservancy in the Red Sea (http://maps.tnc.org/globalmaps.html), and the work from Fatoyinbo and Simard (2013) and Tang et al. (2018) confirms the surface for mangroves. Finally, other habitats present in Africa that provide valuable ecosystem services and were omitted include salt marshes, mudflats, estuaries, sand beaches, and dunes (Barbier et al., 2011; Trégarot et al., 2018). Then, ecosystem services are not uniform across a seascape, and considering the surface area alone puts aside any spatial and temporal differences that should be accounted for, such as reef flat width, for their ability to attenuate wave's height (Ferrario et al., 2014), or seasonal fluctuations in the density and biomass of seagrass (Oreska et al., 2017). The assessment of habitats' vulnerability is one way to account for spatial variability, and has been developed before at a smaller scale (e.g., Ellison, 2015; Ventura and 
da Cunha Lana, 2014), with data on environmental and anthropogenic drivers, the adaptive capacity and sensitivity of marine habitats that could not be assessed here. Our approach is much more simplistic by considering only the demographic pressure but can be easily implemented in other regions. Such an indicator has never been used to adjust the assessment of ecosystem services to our knowledge. Further studies are needed to understand the response of marine habitat functioning (and services) to environmental and anthropogenic pressures. In the context of climate change, implementing effective long-term monitoring is fundamental as habitats should benefit from actions reinforcing their resilience capacity. It requires identifying tipping points and thresholds of foundation species (Moore, 2018) against the cumulative impact of environmental and anthropogenic drivers (Furlan et al., 2019) and developing models to predict coastal marine habitats' trajectories and the benefits that they render to people.

\section{Conclusion}

As human populations continue to increase, particularly in Africa, future population growth and expansion of human settlements in the coastal areas will increase the challenges for conserving species-rich LMEs and maximizing the benefits that humans can gain from nature (Luck, 2007). With an annual loss estimated at 570 billion USD, it questions the effectiveness of policies at national, regional, and continental levels. Therefore, it is crucial to identify economic policy instruments for LMEs' Strategic Action Programme to reverse the degradation of habitats and sustain the goods and services coastal marine habitats provide. The recent set-up of Blue Economy strategies at the African Union, Regional Economics Committees, and country levels (Seychelles and South Africa, for instance) should fill the current science-policy gap, or at least narrow it, as they are addressing, in an integrative manner, the development and the conservation of blue ecosystems.

\section{Acknowledgements}

We are grateful to the anonymous reviewers for critical and constructive feedback.

\section{References}

AU-IBAR, 2019. Africa Blue Economy Strategy. African Union - Interafrican Bureau for Animal resources, Nairobi, Kenya. https://www.au-ibar.org/strategy-documents (accessed June 8, 2020).

Bacon, E., Gannon, P., Stephen, S., Seyoum-Edjigu, E., Schmidt, M., Lang, B., Sandwith, T., Xin, J., Arora, S., and Adham, K.N. 2019. Aichi Biodiversity Target 11 in the like-minded megadiverse countries. Journal for Nature Conservation 51, 125723.

Barbier, E. B., Hacker, S. D., Kennedy, C., Koch, E. W., Stier, A. C., Silliman, B. R. 2011. The value of estuarine and coastal ecosystem services. Ecological monographs, 81, 169-193.

Binet, T., Doumbouya, A., Sall, A. 2012. Évaluation de la valeur socio-économique des écosystèmes marins et côtiers des Aires marines protégées de l'Afrique de l'Ouest. Report for PRCM. 200 pp.

Blamey, L.K., Bolton, J.J. 2018. The economic value of South African kelp forests and temperate reefs: past, present and future. Journal of Marine Systems 188, 172-181.

Bolton, J.J. 2010. The biogeography of kelps (Laminariales, Phaeophyceae): a global analysis with new insights from recent advances in molecular phylogenetics. Helgoland Marine Research, 64, 263279. 
Bonnin, M., Failler, P., Laë, R. 2015. Des AMP pour la résilience des écosystèmes. In : Bonnin, M., Laë, R., Behnassi, M. Aires Marines Protégées Ouest-Africaines : défis scientifiques et enjeux sociétaux. IRD. Paris, France, pp. 197-209.

Braat, L.C., ten Brink, P.E., Klok, T.C. 2008. The Cost of Policy Inaction: The case of not meeting the 2010 biodiversity target. Wageningen, Alterra, Alterra-rapport 1718. $312 \mathrm{p}$.

Bryan, T., Virdin, J., Vegh, T., Kot, C.Y., Cleary, J., Halpin, P.N. 2020. Blue carbon conservation in West Africa: a first assessment of feasibility. Journal of Coastal Conservation 24, 8.

Bunting, P., Rosenqvist, A., Lucas, R., Rebelo, L., Hilarides, L., Thomas, N., Hardy, A., Itoh, T., Shimada, M., Finlayson, C. 2018. The global mangrove watch-a new 2010 global baseline of mangrove extent. Remote Sensing 10, 1669.

Cabral, P., Augusto, G., Akande, A., Costa, A., Amade, N., Niquisse, S., Atumane, A., Cuna, A., Kazemi, K., Mlucasse, R. 2017. Assessing Mozambique's exposure to coastal climate hazards and erosion. International journal of disaster risk reduction 23, 45-52.

Cardinale, B.J., Duffy, J.E., Gonzalez, A., Hooper, D.U., Perrings, C., Venail, P., Narwani, A., Mace, G.M., Tilman, D., Wardle, D.A. 2012. Biodiversity loss and its impact on humanity. Nature 486, 59-67.

CBD 2010. Aichi biodiversity targets. In : COP 10 Decision X/2: Strategic Plan for Biodiversity, 20112020.

CBD 2018. Pan-African Action Agenda on Ecosystem Restoration for Increased Resilience. Convention on Biological Diversity. https://www.cbd.int/doc/c/274b/80e7/34d341167178fe08effd0900/cop-14-afr-hls-04-finalen.pdf (accessed 5 June 2020).

Chukwuone, N.A., Ukwe, C.N., Onugu, A., Ibe, C.A. 2009. Valuing the Guinea current large marine ecosystem: Estimates of direct output impact of relevant marine activities. Ocean \& Coastal Management 52, 189-196.

Clark, C.W. 1990. Mathematical Bioeconomics: the Optimal Management of Renewable Resources. Wiley Interscience, New York.

CMAE, UA, UNEP 2019. Conférence ministérielle africaine sur l'environnement - Promouvoir l'économie bleue/océanique en Afrique : Note du secrétariat. 17th session by African Ministerial Conference on the Environment, African Union and UNEP, Durban, South Africa, 14-15 November 2019.

Cole, S.G., Moksnes, P.-O. 2016. Valuing multiple eelgrass ecosystem services in Sweden: fish production and uptake of carbon and nitrogen. Frontiers in Marine Science 2, 121.

Costanza, R., De Groot, R., Braat, L., Kubiszewski, I., Fioramonti, L., Sutton, P., Farber, S., Grasso, M. 2017. Twenty years of ecosystem services: how far have we come and how far do we still need to go? Ecosystem services 28, 1-16.

Creed, J.C., Engelen, A.H., Bandeira, S., Serrão, E.A. 2016. First record of seagrass in Cape Verde, eastern Atlantic. Marine Biodiversity Records 9, 1-4.

Creel, L., 2003. Ripple effects: population and coastal regions. Washington, DC: Population Reference Bureau, pp. 1-7.

Culhane, F.E., Frid, C.L., Gelabert, E.R., Piet, G., White, L., Robinson, L.A. 2020. Assessing the capacity of European regional seas to supply ecosystem services using marine status assessments. Ocean \& Coastal Management 190, 105154. 
Czúcz, B., Arany, I., Potschin-Young, M., Bereczki, K., Kertész, M., Kiss, M., Aszalós, R., Haines-Young, R. 2018. Where concepts meet the real world: A systematic review of ecosystem service indicators and their classification using CICES. Ecosystem Services, 29, 145-157.

Dawson, T. P., Rounsevell, M. D., Kluvánková-Oravská, T., Chobotová, V., Stirling, A. 2010. Dynamic properties of complex adaptive ecosystems: implications for the sustainability of service provision. Biodiversity and conservation, 19(10), 2843-2853.

Devi, S. 2019. Cyclone Idai: 1 month later, devastation persists. The Lancet 393, 1585.

Dewsbury, B.M., Bhat, M., Fourqurean, J.W. 2016. A review of seagrass economic valuations: gaps and progress in valuation approaches. Ecosystem Services 18, 68-77.

Di Marco, M., Santini, L. 2015. Human pressures predict species' geographic range size better than biological traits. Global Change Biology 21(6), 2169-2178.

Ellison, J. 2015. Vulnerability assessment of mangroves to climate change and sea-level rise impacts. Wetlands Ecology \& Management 23(2), 115-137.

Emerton, L. 2013. Using valuation to make the case for economic incentives: promoting investments in marine and coastal ecosystems as development infrastructure. In: Essam, M. (ed) Economic Incentives for Marine and Coastal Conservation: Prospects, Challenges and Policy Implications. Earthscan, London.

Failler, P., Pètre, É., Binet, T., Maréchal, J.-P. 2015. Valuation of marine and coastal ecosystem services as a tool for conservation: The case of Martinique in the Caribbean. Ecosystem services, 11, 67-75.

Failler, P., Pètre, É., Maréchal, J.-P. 2010. Détermination de la valeur socio-économique des récifs coralliens des mangroves et herbiers de phanérogames de la Martinique. Report for the Direction Régionale de l'Environnement Martinique. $169 \mathrm{pp}$.

Failler, P., Touron-Gardic, G., Traore, M.-S. 2019. Is Aichi Target 11 Progress Correctly Measured for Developing Countries ? Trends in Ecology \& Evolution. Elsevier Ltd. doi: 10.1016/j.tree.2019.07.007.

Fatoyinbo, T.E., Simard, M. 2013. Height and biomass of mangroves in Africa from ICESat/GLAS and SRTM. International Journal of Remote Sensing 34(2), 668-681.

Ferrario, F., Beck, M.W., Storlazzi, C.D., Micheli, F., Shepard, C.C., Airoldi, L. 2014. The effectiveness of coral reefs for coastal hazard risk reduction and adaptation. Nature communications, 5, 1-9.

Foley, N., Armstrong, C.W. 2010. The ecological and economic value of cold-water coral ecosystems. 39 p. Retrieved from https://munin.uit.no/

Folke, C., Carpenter, S., Walker, B., Scheffer, M., Elmqvist, T., Gunderson, L., Holling, C.S. 2004. Regime shifts, resilience, and biodiversity in ecosystem management. Annual Review of Ecology, Evolution and Systematics 35(1), 557-581.

Freiwald, A., Fossa, J.H., Grehan, A., Koslow, T., Roberts, J.M. 2004. Cold-water coral reefs: out of sight-no longer out of mind. UNEP-WCMC, Cambridge, UK, $86 \mathrm{p}$.

Furlan, E., Torresan, S., Critto, A., Lovato, T., Solidoro, C., Lazzari, P., Marcomini, A. 2019. Cumulative Impact Index for the Adriatic Sea: Accounting for interactions among climate and anthropogenic pressures. Science of The Total Environment 670, 379-397.

Greene, C., Kuehne, L., Rice, C., Fresh, K., Penttila, D. 2015. Forty years of change in forage fish and jellyfish abundance across greater Puget Sound, Washington (USA): anthropogenic and climate associations. Marine Ecology Progress Series 525, 153-170.

Haines-Young, R., Potschin, M.B. 2018. Common International Classification of Ecosystem Services (CICES) V5.1 and Guidance on the Application of the Revised Structure. 
Hamukuaya, H. 2011. An Overview of Management of Large Marine Ecosystems and Evidence of Impacts of Climate Change. Paper presented at the COP 17 Oceans Day on behalf of African LME Caucus. Durban, South.

Hebbeln, D., Bender, M., Gaide, S., Titschack, J., Vandorpe, T., Van Rooij, D., Wintersteller, P., Wienberg, C. 2019. Thousands of cold-water coral mounds along the Moroccan Atlantic continental margin: Distribution and morphometry. Marine Geology 411, 51-61.

Herr, D., Landis, E. 2016. Coastal blue carbon ecosystems. Opportunities for nationally determined contributions. Policy brief. Gland, Switzerland: IUCN. Washington, DC: TNC.

Himes-Cornell, A., Grose, S.O., Pendleton, L. 2018a. Mangrove ecosystem service values and methodological approaches to valuation: Where do we stand? Frontiers in Marine Science 5, 376.

Himes-Cornell, A., Pendleton, L., Atiyah, P. 2018b. Valuing ecosystem services from blue forests: a systematic review of the valuation of salt marshes, sea grass beds and mangrove forests. Ecosystem Services, 30, 36-48.

Interwies, E. (2011). The Economic and Social Value of the Guinea Current Ecosystem - a First Approximation. Retrieved from: http://gclme. iwlearn.org/publications/our-publications/theeconomic-and-the- social-value-of-gclme

Interwies, E., Görlitz, S. 2013. Economic and social valuation of the CCLME ecosystem services. In : Rapport au Groupe de travail socioéconomie et commerce du CCLME, vol. 50.

IOC-UNESCO, UNEP 2016. Large Marine Ecosystems: Status and Trends, Summary for Policy Makers. Nairobi, Kenya.

IPBES 2018. The regional assessment report on biodiversity and ecosystem services for Africa. Bonn, Germany. https://ipbes.net/assessment-reports/africa (accessed June 5, 2020).

Jayathilake, D.R.M., Costello, M.J. 2018. A modelled global distribution of the seagrass biome. Biological Conservation 226, 120-126.

Lavery, P.S., Mateo, M.Á., Serrano, O., Rozaimi, M. 2013. Variability in the carbon storage of seagrass habitats and its implications for global estimates of blue carbon ecosystem service. PloS one, 8(9), p.e73748.

Ledoux, L., Turner, R.K. 2002. Valuing ocean and coastal resources: a review of practical examples and issues for further action. Ocean and Coastal Management, 45, 583-616.

LUC 2015. Calculating the economic values of the ecosystem services by Natura 2000 features and sites in Wales. Prepared by LUC for Natural Resources Wales as part of the LIFE Natura 2000 Programme in Wales, Action A9: LIFE N2K Wales: LIFE 11 NAT/UK/385, 21 p.

Luck, G.W. 2007. A review of the relationships between human population density and biodiversity. Biological Reviews 82, 607-645.

MA 2005. Millennium Ecosystem Assessment: Ecosystems and Human Well-being - Synthesis. Island Press, Washington, DC, pp. 155.

McKenzie, L., Nordlund, L.M., Jones, B.L., Cullen-Unsworth, L.C., Roelfsema, C.M., Unsworth, R. 2020. The global distribution of distribution of seagrass meadows. Environmental Research Letters 15, 074041.

Mcleod, E., Chmura, G.L., Bouillon, S., Salm, R., Björk, M., Duarte, C.M., Lovelock, C.E., Schlesinger, W.H., Silliman, B.R. 2011. A blueprint for blue carbon: toward an improved understanding of the role of vegetated coastal habitats in sequestering $\mathrm{CO} 2$. Frontiers in Ecology and the Environment $9(10), 552-560$ 
Moe, S. J., De Schamphelaere, K., Clements, W. H., Sorensen, M. T., Van den Brink, P. J., Liess, M. 2013. Combined and interactive effects of global climate change and toxicants on populations and communities. Environmental Toxicology and Chemistry 32(1), 49-61.

Monteiro, J., Almeida, C., Freitas, R., Delgado, A., Porteiro, F., Santos, R. 2008. Coral assemblages of Cabo Verde: preliminary assessment and description. In Proceedings of the 11th International Coral Reef Symposium, Fort Lauderdale, Florida 7, 1416-1419.

Moore, J.C. 2018. Predicting tipping points in complex environmental systems. Proceedings of the National Academy of Sciences 115, 635-636.

Munro, G. 1979. The optimal management of transboundary renewable resources. Canadian Journal of Economics 12(8), 355-376.

Ndour, A., Laïbi, R.A., Sadio, M., Degbe, C.G., Diaw, A.T., Oyédé, L.M., Anthony, E.J., Dussouillez, P., Sambou, H. 2018. Management strategies for coastal erosion problems in west Africa: Analysis, issues, and constraints drawn from the examples of Senegal and Benin. Ocean \& Coastal Management 156, 92-106.

Nixon, S., Trent, Z., Marcuello, C., Lallana, C. 2003. Europe's water: an indicator-based assessment. European Environment Agency, Copenhagen, $97 \mathrm{p}$.

Nordlund, L.M., Jackson, E.L., Nakaoka, M., Samper-Villarreal, J., Beca-Carretero, P., Creed, J.C. 2018. Seagrass ecosystem services-What's next? Marine pollution bulletin 134, 145-151.

Oreska, M.P., McGlathery, K.J., Porter, J.H. 2017. Seagrass blue carbon spatial patterns at the meadow-scale. PloS one, 12(4), e0176630.

Palmer, M., Filoso, S. 2009. Restoration of ecosystem services for environmental markets. Science 352, 575-576.

Pascal, N., Allenbach, M., Brathwaite, A., Burke, L., Le Port, G., Clua, E. 2016. Economic valuation of coral reef ecosystem service of coastal protection: A pragmatic approach. Ecosystem Services, 21, 72-80.

Pascal, N., Brathwaite, A., Brander, L., Seidl, A., Philip, M., Clua, E. 2018. Evidence of economic benefits for public investment in MPAs. Ecosystem Services 30, 3-13.

Prober, S.M., Doerr, V.A.J., Broadhurst, L.M., Williams, K.J., Dickson, F. 2019. Shifting the conservation paradigm: a synthesis of options for renovating nature under climate change. Ecological Monographs 89(1), 1-23.

QGIS Development Team 2020. QGIS Geographic Information System. Open Source Geospatial Foundation Project. http://qgis.osgeo.org

Ramos, A., Sanz, J.L., Ramil, F., Agudo, L.M., Presas-Navarro, C. 2017. The giant cold-water coral mounds barrier off Mauritania. In Deep-Sea Ecosystems Off Mauritania. (Springer), pp. 481-525.

Satia, B. 2016. An overview of the large marine ecosystem programs at work in Africa today. Environmental Development 17, 11-19.

Schröter, D., Cramer, W., Leemans, R., Prentice, I.C., Araújo, M.B., Arnell, N.W., Bondeau, A., Bugmann, H., Carter, T.R., Gracia, C.A. 2005. Ecosystem service supply and vulnerability to global change in Europe. Science 310(5752), 1333-1337.

Sherman, K. 2019. Large marine ecosystems in Kirk Cochran, J., Bokuniewicz, H., Yager, P. Encyclopedia of Ocean Science $3^{\text {rd }}$ Edition. Academic Press, 709-723.

Sherman, K., Alexander, L. 1986. Variability and Management of Large Marine Ecosystems. American Association for the Advancement of Science Selected Symposium 99. Westview Press, Boulder, Colorado, USA. 
Smith-Hall, C. 2009. Forests sustain livelihoods. In: Lambrechts, C., Wilkie, M.L., Rucevska, I., Sen, M. (Eds) Vital Forest Graphics. Stopping the Downswing? pp. 16-17.

Sumaila, U.R. 2016. Socio-economic benefits of Large Marine Ecosystem valuation: The case of the Benguela Current Large Marine Ecosystem', Environmental Development 17, 244-248.

Sutton-Grier, A.E., Moore, A. 2016. Leveraging carbon services of coastal ecosystems for habitat protection and restoration. Coastal Management 44(3), 259-277.

Tam, J.C., Link, J.S., Large, S. I., Andrews, K., Friedland, K.D., Gove, J., Hazen, E., Holsman, K., Karnauskas, M., Samhouri, J.F., Shuford, R., Tomilieri, N., Zador, S. 2017. Comparing Apples to Oranges: Common Trends and Thresholds in Anthropogenic and Environmental Pressures across Multiple Marine Ecosystems. Frontiers in Marine Science 4(282).

Tang, W., Zheng, M., Zhao, X., Shi, J., Yang, J., Trettin, C.C. 2018. Big geospatial data analytics for global mangrove biomass and carbon estimation. Sustainability 10, 472.

TEEB 2010. The Economics of Ecosystems and Biodiversity: Mainstreaming the Economics of Nature: A Synthesis of the Approach, Conclusions and Recommendations of TEEB. Earthscan, LondonWashington, $39 \mathrm{p}$.

The World Bank 2020. World Development Indicators. Retrieved from: https://databank.worldbank.org/data/

Tittensor, D.P., Walpole, M., Hill, S.L., Boyce, D.G., Britten, G.L., Burgess, N.D., Butchart, S.H., Leadley, P.W., Regan, E.C., Alkemade, R. 2014. A mid-term analysis of progress toward international biodiversity targets. Science 346, 241-244.

Trégarot, E., Catry, T., Pottier, A., Cornet, C., Maréchal, J.-P., Fayad, V., ... Failler, P. (2018). Évaluation des services écosystémiques du Banc d'Arguin, Mauritanie. Report for the National Park of Banc d'Arguin, $398 \mathrm{p}$.

Trégarot, E., Failler, P., Maréchal, J.-P. 2017. Evaluation of coastal and marine ecosystem services of Mayotte: Indirect use values of coral reefs and associated ecosystems. International Journal of Biodiversity Science, Ecosystem Services and Management 13(3), 19-34.

United Nations 2015. Transforming our world: The 2030 Agenda for Sustainable Development. Edited by United Nations: New-York, NY, USA.

United Nations 2019. World Population Prospects 2019. United Nations, Department of Economic and Social Affairs, Population Division, Online Edition. Rev. 1. Retrieved from: https://population.un.org/wpp/.

UNDP 2017. Large Marine Ecosystems and Sustainable Development: A review of Strategic Management Process. United Nations Development Programme, $108 \mathrm{p}$.

UNECA 2016. Africa's Blue Economy: A policy handbook. Retrieved from: https://www.uneca.org/publications/africas-blue-economy-policy-handbook.

UNEP-WCMC 2016a. The State of Biodiversity in Africa: A mid-term review of progress towards the Aichi Biodiversity Targets. Edited by UNEP-WCMC. Cambridge, UK.

UNEP-WCMC 2016b. Impacts du changement climatique sur la biodiversité et les aires protégées en Afrique de l'Ouest, Résumé des résultats du projet PARCC, Aires protégées résilientes au changement climatique en Afrique de l'Ouest. Cambridge, UK. Retrieved from: http://parcc.protectedplanet.net/system/comfy/cms/files/files/000/000/164/original/PARCC_F R_WEB.pdf.

UNEP-WCMC, WorldFish Centre, WRI, TNC 2018. Global distribution of warm-water coral reefs, compiled from multiple sources including the Millennium Coral Reef Mapping Project. Version 4.0. Includes contributions from IMaRS-USF and IRD (2005), IMaRS-USF (2005) and Spalding et 
al. (2001). Cambridge (UK): UN Environment World Conservation Monitoring Centre. Retrieved from: http://data.unep-wcmc.org/datasets.

UNEP-WCMC, Short, F. 2017. Global Distribution of Seagrasses (version 6.0). Sixth update to the data layer used in Green and Short (2003), UN Environment World Conservation Monitoring Centre.

UNEP, GRID-Arendal 2016. The Socio-Economics of the West, Central and Southern African Coastal Communities: A Synthesis of Studies Regarding Large Marine Ecosystems. Nairobi, Abidjan and Arendal. Retrieved from: https://gridarendal-websitelive.s3.amazonaws.com/production/documents/:s_document/323/original/AfricanLME_screen. pdf?1491297440.

Veen, J., Dallmeijer, H., Veen, T. 2018. Selecting piscivorous bird species for monitoring environmental change in the Banc d'Arguin, Mauritania. Ardea 106, 5-19.

Vegh, T., Potouroglou, M. 2018. High Level Assessment of Seagrass Ecosystem Services in Western Africa. ResilienSEA, MAVA Fondation pour la Nature, 36 p. Retrieved from: https://resiliensea.org

Ventura, A.d.O.B., da Cunha Lana, P. 2014. A new empirical index for assessing the vulnerability of peri-urban mangroves. Journal of environmental management 145, 289-298.

Wangai, P.W., Burkhard, B., Müller, F. 2016. A review of studies on ecosystem services in Africa. International Journal of Sustainable Built Environment 5(2), 225-245.

Ward-Paige, C.A., Mora, C., Lotze, H. K., Pattengill-Semmens, C., McClenachan, L., Arias-Castro, E., Myers, R.A. 2010. Large-Scale Absence of Sharks on Reefs in the Greater-Caribbean: A Footprint of Human Pressures. PloS one 5, e11968.

Wernberg, T., Krumhansl, K., Filbee-Dexter, K., Pedersen, M.F. 2019. Status and trends for the world's kelp forests. In: World seas: an environmental evaluation (pp. 57-78). Academic Press.

Whitney, C.K., Bennett, N.J., Ban, N.C., Allison, E.H., Armitage, D., Blythe, J.L., Burt, J.M., Cheung, W., Finkbeiner, E.M., Kaplan-Hallam, M., Perry, I., 2017. Adaptive capacity: from assessment to action in coastal social-ecological systems. Ecology and Society, 22(2), 22.

Willcock, S., Hooftman, D., Sitas, N., O'Farrell, P., Hudson, M.D., Reyers, B., Eigenbrod, F., Bullock, J.M. 2016. Do ecosystem service maps and models meet stakeholders' needs? A preliminary survey across sub-Saharan Africa. Ecosystem Services 18, 110-117.

Yesson, C., Taylor, M.L., Tittensor, D.P., Davies, A.J., Guinotte, J., Baco, A., Black, J., Hall-Spencer, J.M., Rogers, A.D. 2012. Global habitat suitability of cold-water Octocorals. Journal of Biogeography 39: $1278-1292$. 
Table A1. Demographic parameters associated with Large Marine Ecosystems from adjacent

757 countries and derived habitat functionality index.

\begin{tabular}{lcccc}
\hline $\begin{array}{l}\text { Large Marine Ecosystems (LMEs) } \\
\text { and the additional region of Africa }\end{array}$ & Population ${ }^{\text {a }}$ & $\begin{array}{c}\text { Population Density }^{\text {a* }} \\
\text { [inhabitants/km }{ }^{2}\end{array}$ & $\begin{array}{c}\text { Population } \\
\text { Growth Rate } \\
\text { [\%/year] }\end{array}$ & $\begin{array}{c}\text { Habitat } \\
\text { Functionality } \\
\text { Index }\end{array}$ \\
\hline African Islands of the Indian Ocean & $2,264,560$ & $502.23 * * *$ & 0.41 & $50 \%$ \\
Agulhas Current LME & $95,896,747$ & $43.64 * *$ & 2.23 & $75 \%$ \\
Arabian Sea LME & $6,217,608$ & 29.00 & 2.69 & $50 \%$ \\
Benguela Current LME & $58,574,052$ & 23.46 & 2.42 & $75 \%$ \\
Canary Current LME & $51,167,231$ & 47.92 & 1.82 & $75 \%$ \\
Guinea Current LME & $436,506,189$ & 83.94 & 2.67 & $25 \%$ \\
Mediterranean Sea LME & $109,474,334$ & 44.86 & 1.71 & $75 \%$ \\
Red Sea LME & $112,454,878$ & 64.47 & 2.11 & $75 \%$ \\
Somali Coastal Current LME & $123,843,160$ & 48.08 & 2.67 & $50 \%$ \\
\hline
\end{tabular}

a Source: United Nations, 2019.

$759 *$ these calculations are based on population density data on a national level. However, coastal

760 populations in each country are assumed to be more concentrated.

** Madagascar wasn't used to calculate the population density here, but its density is close to the calculated average (48 inhabitants per $\mathrm{km}^{2}$ ). Comoros and Mayotte, whose density are higher, weren't integrated into the calculation because of their very small surface area. population density. 